\title{
Does Parental Mediation of Media Influence Child Outcomes? A Meta-Analysis on Media Time, Aggression, Substance Use, and Sexual Behavior
}

\author{
Kevin M. Collier \\ Brigham Young University - Provo \\ Sarah M. Coyne \\ Brigham Young University - Provo, smcoyne@byu.edu \\ Eric E. Rasmussen \\ Texas Tech University

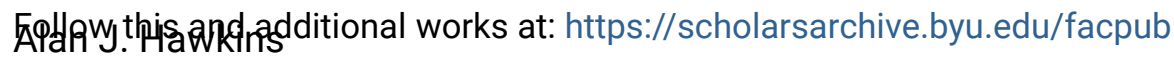

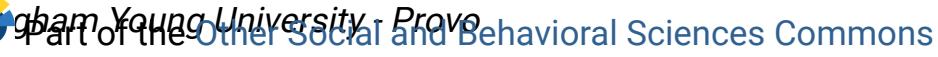

\section{Laura M. Padilla-Walker \\ Briggimal YBubdicatiersifyitation}

Collier, K. M., Coyne, S. M., Rasmussen, E., Hawkins, A. J., Padilla-Walker, L. M., Erickson, S., Memmott-Elison, M. (2016). Does parental mediation of media influence child outcomes? A See next page for additional authors

meta-analysis on media time, aggression, substance use, and sexual behavior. Developmental

Psychology, 52, 798-812.

\section{BYU ScholarsArchive Citation}

Collier, Kevin M.; Coyne, Sarah M.; Rasmussen, Eric E.; Hawkins, Alan J.; Padilla-Walker, Laura M.; Erickson, Sage E.; and Memmott-Elison, Madison K., "Does Parental Mediation of Media Influence Child Outcomes? A Meta-Analysis on Media Time, Aggression, Substance Use, and Sexual Behavior" (2016). Faculty Publications. 4021.

https://scholarsarchive.byu.edu/facpub/4021

This Peer-Reviewed Article is brought to you for free and open access by BYU ScholarsArchive. It has been accepted for inclusion in Faculty Publications by an authorized administrator of BYU ScholarsArchive. For more information, please contact ellen_amatangelo@byu.edu. 


\section{Authors}

Kevin M. Collier, Sarah M. Coyne, Eric E. Rasmussen, Alan J. Hawkins, Laura M. Padilla-Walker, Sage E.

Erickson, and Madison K. Memmott-Elison 


\title{
Does Parental Mediation of Media Influence Child Outcomes? A Meta-Analysis on Media Time, Aggression, Substance Use, and Sexual Behavior
}

\author{
Kevin M. Collier and Sarah M. Coyne \\ Brigham Young University
}

Eric E. Rasmussen
Texas Tech University

\author{
Alan J. Hawkins, Laura M. Padilla-Walker, \\ Sage E. Erickson, and Madison K. Memmott-Elison \\ Brigham Young University
}

\begin{abstract}
The current study examined how parental mediation of media (restrictive mediation, active mediation, and coviewing) influenced child outcomes. Three meta-analyses, 1 for each type of mediation, were conducted on a total of 57 studies. Each analysis assessed the effectiveness of parental mediation on 4 pertinent child outcomes: media use, aggression, substance use, and sexual behavior. The overall results indicated small, but significant relationships between child outcomes and restrictive mediation $\left(r_{+}=\right.$ $-.06)$, and coviewing $\left(r_{+}=.09\right)$. Overall active mediation was nonsignificant, though active mediation was individually related to lower levels of aggression $\left(r_{+}=-.08\right)$, sexual behavior $\left(r_{+}=-.06\right)$, and substance use $\left(r_{+}=-.11\right)$. This analysis revealed that parents may have the ability to mitigate some of the adverse effects of the media by using certain mediation strategies. Overall, a cooperative effort from the communication and parenting fields is necessary for a comprehensive analysis of parental mediation as well as a disentanglement of the various parental mediation measures.
\end{abstract}

Keywords: parental mediation, parental monitoring, media use, aggression, substance use, sexual behavior

Over the past decade, children's media use and exposure to media have significantly increased. Adolescents spend almost 8 hours a day using media, cramming nearly 11 hours of media content into those hours (Rideout, Foehr, \& Roberts, 2010). This amount far exceeds the American Academy of Pediatrics (AAP) suggested 2 hours or less of entertainment media per day to encourage optimal development (AAP, 2001). Exposure to certain types of media content is related to a number of negative outcomes for children and adolescents including problems at home or school (Rideout et al., 2010); verbal, physical, and relational aggression (e.g., Anderson et al., 2003; Brummert Lennings, \& Warburton, 2011; Bushman \& Anderson, 2009; Coyne \& Archer, 2004; Coyne, Robinson, \& Nelson, 2010); poor academic performance (Cummings \& Vandewater, 2007); substance use (Dalton et al.,

This article was published Online First February 25, 2016.

Kevin M. Collier and Sarah M. Coyne, School of Family Life, Brigham Young University; Eric E. Rasmussen, College of Media \& Communication, Texas Tech University; Alan J. Hawkins, Laura M. Padilla-Walker, Sage E. Erickson, and Madison K. Memmott-Elison, School of Family Life, Brigham Young University.

Kevin M. Collier is now at The Ohio State University in the Department of Communication.

Correspondence concerning this article should be addressed to Kevin M. Collier, Department of Communication, The Ohio State University, 3049 Derby Hall, 154 N Oval Mall, Columbus, OH 43210. E-mail: collier .262@osu.edu
2003; Schooler, Feighery, \& Flora, 1996); attention problems (Christakis, Zimmerman, DiGiuseppe, \& McCarty, 2004); and risky sexual behavior (Escobar-Chaves et al., 2005). Parents may play a significant role in influencing their child's perceptions and use of the media since the majority of a child's media consumption occurring in his or her home (Hogan, 2012). One technique that parents and researchers have discovered to be effective in mitigating some media effects is termed parental mediation of media. This study will differentiate between the types of parental mediation and will use meta-analytic techniques to examine how each may influence child and adolescent outcomes.

\section{Types of Parental Mediation}

Parental mediation (also called parental media monitoring: Padilla-Walker, Coyne, Fraser, Dyer, \& Yorgason, 2012) involves the interactions parents have with their children about media use, including restrictive, active, and coviewing (Valkenburg, Krcmar, Peeters, \& Marseille, 1999). Restrictive mediation (i.e., cocooning and rule setting) occurs when parents generate rules that limit their child's time spent consuming media (i.e., TV, video games, and/or Internet) or the content their child is allowed to access (e.g., Valkenburg et al., 1999). Conversely, active mediation (i.e., evaluative mediation, prearming, and discussion) occurs when parents discuss character's choices, central themes, or other components of the media consumed with their child, with the intent to promote critical thinking of the media (Austin, 1993). For example, parents using active mediation would ask their child about possible con- 
sequences of a TV character's choices, followed by a discussion between parent and child. Subcategories of active mediation are beginning to be investigated including positive, negative, and neutral active mediation. Positive active mediation refers to messages that endorse or praise content (i.e., "I love the way she is treating her friend in this show") whereas negative active mediation refutes or condemns mediated content (i.e., "That's not real") (Austin, Bolls, Fujioka, \& Engelbertson, 1999). When parents' comments are neither negative nor positive, neutral active mediation is being used (i.e., "He is laughing"; Nathanson 2001a). Finally, coviewing (i.e., coplaying, coreading, and colistening) consists of parents consuming media with their child (Dorr, Kovaric, \& Doubleday, 1989). For instance, a parent who listens to music with their child would be engaging in colistening. Coviewing also splits into two subgroups: intentional coviewing when parents are concerned about the influence of media on their child; and passive coviewing when parents circumstantially are in the same room when their child or adolescent is consuming media, or vice versa (Chakroff \& Nathanson, 2008).

\section{Theoretical Background}

The vast majority of parental mediation studies do not explicitly discuss theory. However, the general principles behind parental mediation can be well explained by a number of family and developmental theories. General parenting strategies include monitoring a child's or adolescent's attitudes and behavior to protect them from physical harm and to illicit more socially appropriate attitudes and behaviors. Recent research by Kerr, Stattin, and Burk (2010) found that parents obtain more knowledge about daily adolescent activities from youth disclosure than from classic parental monitoring efforts (i.e., parental control and solicitation). Parental monitoring of peer relationships, a similar literature to parental mediation, entails parents consulting children and adolescents about their relationships in response to specific incidences regarding peers. Additionally, parents try to prepare their children for the possibility of particular problems that occur among peers. Notably, parents are heavily involved in regulating peer interactions, though this decreases with age (Mounts, 2011).

Restrictive mediation of media may be viewed as a form of parental monitoring. This strategy is an involved process with parents having direct supervision and control of their child's media activity to protect from harmful exposure leading to negative outcomes, comparable to how parents monitor peers. Younger children may be more accepting of restrictions, as they have less need for autonomy and may view parental rules as absolute (Nathanson, 2001b). As the child grows into adolescence, parents are less able to mediate and monitor due to increasing amounts of time spent outside the home and as portable devices become more accessible (Kerr et al., 2010). Adolescence is a period of autonomy seeking and restrictive mediation (and other types of parental control) may decrease the chance that adolescents will openly disclose information to their parents, thus increasing negative adolescent outcomes (Kerr et al., 2010). Self-determination theory may also relate to restrictive mediation. This theory explores human motivation without external influence and interference (Grolnick, Deci, \& Ryan, 1997). Autonomy and competence are two fundamental human needs and serve as intrinsic motivation for a child, adolescent, and adult. Restrictive mediation, a form of parental control that does not generally allow for internally regulated values and behaviors, may counteract parental efforts as they guide and teach adolescents to begin to make independent and informed decisions. Adolescents require more freedom and responsibility to begin making their own choices, which may be encouraged through active rather than restrictive mediation.

Active mediation also coincides well with self-determination theory, granting more autonomy to child and adolescent behavior and attitudes in general as well as in regards to media. Parents encourage internally regulated values and open disclosure about media use and exposure to negative content when using active mediation (Grolnick et al., 1997; Kerr et al., 2010). Parent-child open disclosure at an early age may increase the likelihood of adolescent disclosure about friends, school, and daily activities including media consumption (Kerr \& Stattin, 2000). Rather than requiring a child or adolescent to be compliant to the parental standards of media, parents teach and clarify their media standards, allowing critical thinking skills to be obtained (Grusec \& Goodnow, 1994). However, negative active mediation may threaten autonomy and discourage critical thinking by potentially forcing a child to choose between their interests and parental disapproval. Similarly, parents must be wary of introducing topics that their child is not developmentally ready for, such as drug-related, sexual, or complex moral topics (Nathanson, 2002). A balance between restrictive and active mediation may be the most developmentally beneficial for children.

Social learning theory states that children are very perceptive of what their parents are doing and may model their behaviors and attitudes toward media to conform to parents' use (Bandura, 1977). Unlike restrictive and active mediation, parents who coview send an implicit message of approval of any media content consumed together by their mere presence of viewing the joint content, intentional or inadvertent. Children may also increase their use of media and learn behaviors and attitudes from this type of parental mediation. Coviewing, as much as restrictive or active mediation, has the capacity to promote acceptance of positive as well as negative behaviors in the media.

\section{Effects of Parental Mediation}

Parental mediation and media exposure are both factors in determining a host of child outcomes. As socialization agents, both media (Chakroff \& Nathanson, 2008) and parents (Hogan, 2012) can influence children's attitudes, beliefs, and behaviors. The formative years of parental mediation research served to determine that parental mediation does indeed make a difference in children's lives. Subsequent research, however, goes beyond in describing the effectiveness of the mediation to investigating the cognitive and affective processes through which parental mediation influences children (Rasmussen, 2014). Research into these processes suggests that each type of parental mediation works first to alter children's perceptions of content presented in the media or the medium itself, whether on purpose or not. These altered perceptions then affect children's attitudinal or behavioral outcomes. For example, restricting an adolescent's cell phone use at school may help the adolescent recognize that the cell phone may interrupt his or her academic progress and then he or she may choose to not use the medium during school. In the following sections, we examine 
how the three types of parental mediation may mitigate or exacerbate effects of media.

\section{Restrictive Mediation}

Of the three types of parental mediation, restrictive is the most common type in American homes and has shown to be effective in reducing negative outcomes of media consumption during childhood (Rideout et al., 2010). However, the research on restrictive mediation tends to be rather inconsistent, depending on the type of medium, content, or outcome analyzed. For example, restrictive mediation has been utilized by parents to decrease overall media use (i.e., Barradas, Fulton, Blanck, \& Huhman, 2007; Carlson et al., 2010; Cillero \& Jago, 2011; Livingstone \& Helsper, 2008; Nathanson, 2002; Ramirez et al., 2011; te Velde et al., 2011), but the use of content restrictions appears to increase the amount of time spent viewing TV in at least one study (Vandewater, Park, Huang, \& Wartella, 2005). Additionally, rules regarding TV content decrease the amount of violent and pornographic content (Livingstone \& Helsper, 2008; Woolf, 2009) and child entertainment (i.e., cartoons; Truglio, Murphy, Oppenheimer, Huston, \& Wright, 1996), and increase educational and prosocial content viewed by children (Woolf, 2009). Accordingly, restrictive mediation on both the amount of time spent consuming media and the content consumed are influential on child and adolescent behaviors and attitudes (Brown et al., 2006; Rideout et al., 2010).

In terms of behavior and attitudes, restrictive mediation can be both positive and negative. Setting rules about TV (Nathanson, 1998, 1999; Valkenburg, Piotrowski, Hermanns, \& de Leeuw, 2013), movies (Valkenburg et al., 2013), and video games (AbelCooper, 2001; Engelhardt \& Mazurek, 2013) is associated with decreased verbal and physical aggressive attitudes and behaviors such as name calling, pushing, tripping, and hitting in children and adolescents. However, other studies show that restricting time and content of TV is related to an increase of imitated aggressive behavior (Vandewater et al., 2005), especially for younger children (Nathanson, 2002). Additionally, adolescents' likelihood of experimentation with substances (i.e., alcohol and tobacco: Dalton et al., 2006; Hanewinkel, Morgenstern, Tanski, \& Sargent, 2008) and sexual behavior (Ashby, Arcari, \& Edmonson, 2006; Bersamin et al., 2008; Fisher et al., 2009) is decreased when parental restrictive mediation of time and content are utilized, although some findings suggest higher levels of restrictive mediation in regards to sexual content are associated with higher levels of sexual activity, potentially promoting a "forbidden fruit" complex in adolescence (Nikken \& de Graaf, 2013). In sum, though there appears to be some evidence that restrictive mediation may be a useful tool in mitigating harmful media effects, some areas are inconsistent and often depend on child characteristics, such as gender or age.

\section{Active Mediation}

Active mediation is a means of exploring and clarifying media content between parents and their children, with an aim of helping children to become critical consumers of the media. In general, the research on active mediation tends to be less discordant compared to the restrictive mediation literature, though inconsistencies do exist. In terms of media time, active mediation is associated with fewer hours spent viewing media for children ages 2-11 (Barkin et al., 2006), especially for girls (Van den Bulck \& Van den Bergh, 2000). However, little is known about whether active mediation influences time spent using media for preschoolers and older adolescents (Harrison \& Liechty, 2012; Schooler, Kim, \& Sorsoli, 2006). These active discussions with children about media increase informative and prosocial content (St. Peters, Fitch, Huston, Wright, \& Eakins, 1991; Woolf, 2009) and reduce the amount of aggressive content (Linder \& Werner, 2012; Nathanson, 1999) viewed by children and adolescents. Active mediation also decreases the amount of aggressive behavior in children and adolescents (Linder \& Werner, 2012; Nathanson, 1998, 1999; Singer, Singer, Desmond, Hirsch, \& Nicol, 1988). Specifically, when parents openly talk about violent TV, children and adolescents develop negative attitudes toward programs that feature violence and aggressive characters, with a decreased likelihood of viewing violent TV (Rasmussen, 2014). Current research on media time, media content, and aggressive behavior appears to have mostly positive results when parents use active mediation.

Active mediation is also used to discuss substance use and sexual behaviors; however, the research tends to be more mixed concerning these outcomes. For example, active mediation of substance use in the media was positively related to child substance use (Austin \& Chen, 2003; Fujioka \& Austin, 2003) suggesting that talking to younger children about substances is a maladaptive practice; whereas in adolescence, active mediation is effective in preventing and/or reducing substance use (Austin, Pinkleton, \& Fujioka, 2000). Active mediation efforts can sometimes backfire and increase the likelihood of unprotected sex as well as negative sexual attitudes in adolescents (i.e., men are sex-driven or women are sexual objects: Guo \& Nathanson, 2011); conversely, active mediation predicts fewer intentions for oral and vaginal sex (Fisher et al., 2009). In sum, there are a number of inconsistencies for the active mediation literature, especially in terms of health behaviors, substance use, and sexual outcomes. These inconsistencies may be due to a number of moderating influences including differing measures, gender, age of child, and type of media examined.

\section{Coviewing}

Research regarding the effect of coviewing on child and adolescent behavior is also inconsistent. Coviewing is associated with increased child use of TV, films, music, and books (Harrison \& Liechty, 2012; Parkes, Wight, Hunt, Henderson, \& Sargent, 2013; Sun, 2009). Parental coviewing also influences the time spent viewing specific types of media, including prosocial content (Woolf, 2009), as well as adult-themed and aggressive content (St. Peters et al., 1991). In terms of aggression, coviewing has been shown to increase child and adolescent aggressive behavior and attitudes (Nathanson, 1999, 2001a; Vandewater et al., 2005); however results are more positive when parents coplay video games (of all types) with their daughters, leading to a decrease in aggressive behavior (Coyne, Padilla-Walker, Stockdale, \& Day, 2011).

Somewhat contradictory results have been found among the research regarding whether parental coviewing of media influences substance use. For example, coviewing is negatively associated with substance use in one study (Dalton et al., 2006), while another reports a positive association (de Leeuw, Blom, \& Engels, 2014). These differences may be due to measurement differences, 
varying sample sizes and age of participants. Finally, in terms of sexual content, studies agree that coviewing sexual media with adolescents is related to less risky behavior, including later initiation of sexual intercourse and fewer sexual partners (Bersamin et al., 2008; Fisher et al., 2009; Guo \& Nathanson, 2011). Inconsistencies may arise in parental mediation research due to certain moderators within the data, which explain different trends and/or associations.

\section{Potential Moderators}

The central aim of this study was to examine whether parental mediation is successful in mitigating known media effects. The literature, in its current status, contains many inconsistencies that make this analysis difficult. A substantial piece of this instability develops due to the moderators presented below. For example, different types of mediation (i.e., restrictive, active, and coviewing) may be more beneficial for different ages, genders, media, and so forth. We have organized our analyses to account for these various moderators as described below.

First, the medium being monitored may moderate effects, with TV and video games among the most highly monitored media (Carlson et al., 2010; Harrison \& Liechty, 2012; Patriarca, Di Giuseppe, Albano, Marinelli, \& Angelillo, 2009; Ramirez et al., 2011). Parental mediation may also function differently for different ages of children. For example, one major developmental task of adolescence involves developing a sense of autonomy (Steinberg, 2013). Consequently, restrictive mediation may be a positive parental tool in childhood, but less so in adolescence where developing autonomy is a more essential developmental task. Additionally, certain types of active mediation may be more effective for an adolescent audience that may have developed the higher order functioning necessary to digest complicated media messages (Barradas et al., 2007; Nathanson, 2002). We explored whether different types of mediation influenced child and adolescent attitudes or behaviors more and also considered whether study design (i.e., cross-sectional, longitudinal), parental mediation reporter (parent, child, or both), outcome reporter (parent, child, or both) and type of publication (i.e., published or unpublished) would moderate the magnitude of the association between parental mediation and the outcomes.

\section{Current Study}

The research on parental mediation on child and adolescent outcomes tends to be mixed and contradictory. This study will use meta-analytic techniques to examine the following research questions (RQs):

RQ1. What is the association between restrictive mediation and the specified child and adolescent outcomes?

RQ2. What is the association between active mediation and the specified child and adolescent outcomes?

RQ3. What is the association between coviewing and the specified child and adolescent outcomes?

RQ4. What variables moderate the above associations between parental mediation and the child and adolescent outcomes?

Each type of parental mediation (restrictive, active, and coviewing) will be examined in relation to a number of child attitudes and behaviors, specifically, media time (general and content specific), aggression, substance use, and sexual behavior. As this is the first meta-analysis conducted on parental mediation, we chose these child and adolescent outcomes due to (a) their frequency in media content, (b) research showing real-world problems in children (i.e., society is concerned about children being aggressive, engaging in risky sex, and using substances), and (c) each of the outcomes having been examined in the context of parental mediation. Our analyses will differentiate between the types of mediation and will assess how the different styles of mediation influence outcomes.

\section{Method}

\section{Search Strategies}

In order to obtain all relevant studies for this meta-analysis, a three-step approach was used. First, a team of eight trained undergraduate students used PsycINFO, MEDLINE, Communication \& Mass Media Complete, and Google Scholar as databases. The following key words were used: parent ${ }^{*}$, caregiver $^{*}$, guardian $^{*}$, adult $^{*}$, media, $T V^{*}$, movie $^{*}$, Internet ${ }^{*}$, video games, mediation, monitoring, coviewing, co-viewing, coplaying, co-playing, active mediation, active monitoring, restrictive mediation, restrictive monitoring, rules, parental control, cocooning, evaluative guidance, explanation, instructive mediation, interpretive mediation, evaluative mediation, prearming, pre-arming, TV cohesion, promotive mediation, and discussion. These searches covered journal articles, master's theses, and doctoral dissertations from the year each database started until November 2015. Finally, authors publishing at least two studies on parental mediation were contacted to request any unpublished studies. Of the studies reviewed in the initial search, 106 were found to be relevant to this study as explained next.

\section{Inclusion Criteria}

To be included in this meta-analysis the articles had to meet four criteria. (a) The study needed to include some measure or manipulation of parental mediation including active mediation, restrictive mediation, coviewing, or a combination of the three. Although a small minority of studies distinguished between positive, neutral, and negative active mediation, each was collapsed into general active mediation; similarly, intentional and passive coviewing were equally nondistinguished and were collapsed into general coviewing. Studies that specified parental discussion during coviewing were treated as active mediation, but otherwise were treated as coviewing. (b) Each study needed to contain one of the specified child outcomes in regards to attitudes or behaviors: media time (general and content specific), aggression, substance use, or sexual behavior. Originally, we planned to keep media time of general and media time of specific types of content (i.e., violent, sexual, etc.) separate, but too few studies were conducted on content specific media time to be included in this analysis. Therefore, time spent in a particular media content was combined with the general media time variable. (c) There must have been a zero-order correlation, partial correlation, beta coefficient, odds ratio, log rate ratio, or a $t$ test. (d) Finally, we only included studies that presented outcomes for children under the age of 18. Individuals $18+$ are typically no longer constrained to their parents' 
media regulations and were not included in the current metaanalysis.

Of the 106 studies that met the initial inclusion characteristics, 43 were excluded for not containing the right statistical data (i.e., hazards ratio, relative risk ratio) to analyze despite efforts made to contact corresponding authors for the statistics. Additionally, several studies used the same dataset for multiple publications; accordingly, 13 reports were collapsed into five studies with independent samples in our data set. Of the initial 106 studies, 57 were included in the quantitative synthesis, representing $N=57,788$ total participants (see Figure 1). A more detailed view of the studies within the meta-analysis can be found in Table 1 .

\section{Measures of Child and Adolescent Outcomes}

Media use was the most common outcome with parental mediation as the predictor $(k=35)$, followed by aggression $(k=12)$, substance use $(k=7)$, sexual outcomes $(k=6)$, and media content $(k=5)$.

Media time/content. Media use included the time spent engaging with any electronic form of media (i.e., TV, video games, movies, etc.). Additionally, time with specific content was examined (i.e., prosocial, aggressive, educational, etc.).

Aggression. Child and adolescent aggression was analyzed if a study contained verbal, physical, or relational aggressive attitudes and/or behaviors as an outcome. Sexual aggression was not included in this analysis.

Substance use. Substance use included variables of children and youth consuming substances (i.e., alcohol, tobacco, and other licit and illicit drugs), attitudes toward substance use, their likelihood of consuming substances, or their desires for substances.

Sexual outcomes. Child and adolescent attitudes or behaviors in reference to sexual behavior (i.e., kissing, petting, and any form

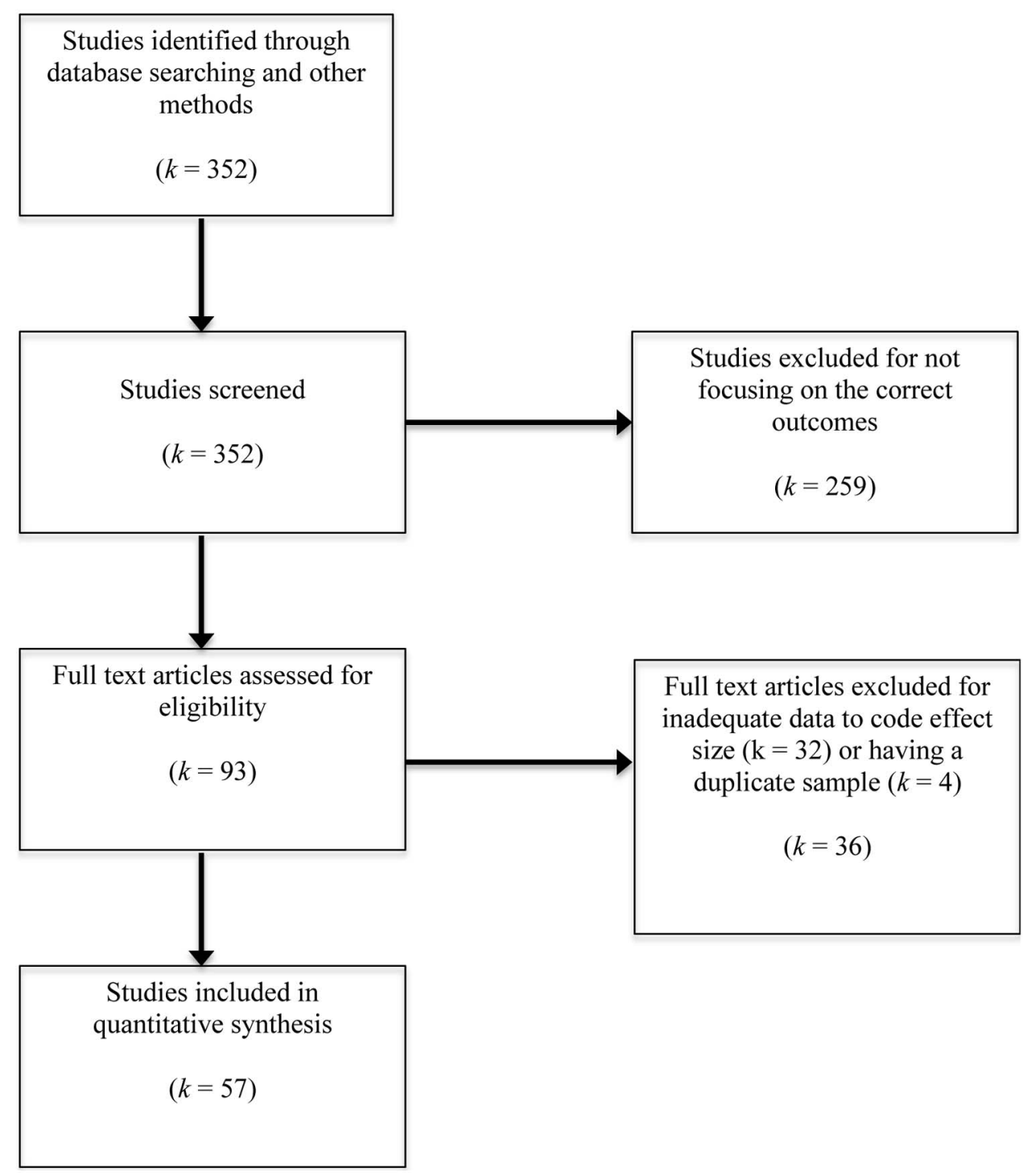

Figure 1. Flowchart of inclusion/exclusion decisions. 
Table 1

Sample Size, Parental Mediation Type, Outcomes, and Selected Moderators for Included Studies

\begin{tabular}{|c|c|c|c|c|c|c|c|c|c|}
\hline Study & $N$ & $\begin{array}{l}\text { Type of } \\
\text { parental } \\
\text { mediation }\end{array}$ & $\begin{array}{l}\text { Parental } \\
\text { mediation } \\
\text { report }\end{array}$ & Outcome & $\begin{array}{l}\text { Outcome } \\
\text { report }\end{array}$ & Age & $\begin{array}{l}\text { Media } \\
\text { type }\end{array}$ & $\begin{array}{l}\text { Study } \\
\text { type }\end{array}$ & $\begin{array}{c}\text { Att vs. } \\
\text { Beh }\end{array}$ \\
\hline Abel-Cooper, 2001 & 355 & $\mathrm{RM}$ & Child & AG & Child & A & VG & $\mathrm{CS}$ & Beh \\
\hline Austin \& Chen, 2003 & 300 & $\mathrm{AM}$ & Child & SU & Child & A & TV & $\mathrm{CS}$ & Beh \\
\hline Austin et al., 2000 & 573 & $\mathrm{AM}$ & Child & SU & Child & A & TV & CS & Both \\
\hline Barkin et al., 2006 & 1,831 & $\mathrm{AM}$ & Parent & MT & Parent & $\mathrm{C}$ & TV & $\mathrm{CS}$ & Beh \\
\hline Barradas et al., 2007 & $344-355$ & $\mathrm{RM}$ & Parent & MT & Child & A & TV & CS & Beh \\
\hline \multicolumn{10}{|l|}{ Bauer,Neumark-Sztainer, Fulkerson, } \\
\hline Hannan, \& Story, 2011 & 253 & RM & Parent & MT & Child & A & TV & $\mathrm{CS}$ & Beh \\
\hline Borzekoski \& Robinson, 2007 & 627 & $\mathrm{AM}, \mathrm{RM}, \mathrm{CO}$ & Parent & MT & Parent & $\mathrm{C}$ & TV & $\mathrm{CS}$ & Beh \\
\hline Carlson et al., 2010 & 7,415 & $\mathrm{RM}$ & Parent & MT & Parent & $\mathrm{C}$ & TV & CS & Beh \\
\hline Choo, Sim, Liau, Gentile, \& Khoo, 2015 & 2974 & RM & Child & MT & Child & $\mathrm{C}$ & VG & $\mathrm{CS}$ & Beh \\
\hline Coyne et al., 2011 & $101-186$ & $\mathrm{CO}$ & Children & AG, MT, MC & Both & A & VG & $\mathrm{CS}$ & Beh \\
\hline Dalton et al., 2006 & 2,606 & $\mathrm{RM}, \mathrm{CO}$ & Child & SU & Child & $\mathrm{C}$ & TV & CS & Beh \\
\hline Darweesh \& Mahmoud, 2014 & 400 & RM & Child & MT & Child & A & IN & $\mathrm{CS}$ & Beh \\
\hline Desmond \& Duran, 2011 & 140 & RM & Child & MT & Child & A & MM & CS & Beh \\
\hline Engelhardt \& Mazurek, 2014 & 169 & RM & Parent & AG & Parent & $\mathrm{C}$ & MM & $\mathrm{CS}$ & Beh \\
\hline Fisher et al., 2009 & 1,012 & $\mathrm{AM}, \mathrm{RM}, \mathrm{CO}$ & Child & SX & Child & A & TV & CS & Both \\
\hline Fujioka \& Austin, 2003 & 198 & $\mathrm{AM}$ & Parent & SU & Child & A & TV & $\mathrm{CS}$ & Att \\
\hline Guo \& Nathanson, 2011 & 180 & $\mathrm{AM}, \mathrm{RM}, \mathrm{CO}$ & Child & SX & Child & A & TV & $\mathrm{CS}$ & Both \\
\hline Hanewinkel et al., 2008 & 2,110 & $\mathrm{RM}$ & Child & SU & Child & $\mathrm{C}$ & $\mathrm{M} / \mathrm{V}$ & $\mathrm{CS}$ & Beh \\
\hline Hardy et al., 2006 & 343 & $\mathrm{RM}, \mathrm{CO}$ & Both & MT & Both & $\mathrm{C}$ & TV & $\mathrm{CS}$ & Beh \\
\hline Harrison \& Liechty, 2012 & 402 & $\mathrm{AM}, \mathrm{RM}, \mathrm{CO}$ & Parent & MT & Parent & $\mathrm{C}$ & MM & $\mathrm{CS}$ & Beh \\
\hline \multicolumn{10}{|l|}{ Johnson, Chen, Hughes, \& O'Connor, } \\
\hline 2015 & 287 & $\mathrm{RM}, \mathrm{CO}$ & Parent & MT & Parent & $\mathrm{C}$ & TV & $\mathrm{CS}$ & Beh \\
\hline Lee, 2013 & 566 & $\mathrm{RM}$ & Parent & MT & Child & $\mathrm{C}$ & IN & CS & Beh \\
\hline Lin \& Atkin, 1989 & 444 & $\mathrm{AM}, \mathrm{RM}$ & Child & MT & Child & A & MM & $\mathrm{CS}$ & Beh \\
\hline Linder \& Werner, 2012 & $50-103$ & $\mathrm{AM}$ & Parent & AG, MT, MC & Child & $\mathrm{C}$ & MM & $\mathrm{CS}$ & Att \\
\hline Livingstone \& Helsper, 2008 & 632 & $\mathrm{AM}, \mathrm{RM}$ & Both & MT, MC & Child & A & IN & $\mathrm{CS}$ & Beh \\
\hline McDade-Montez et al., 2015 & 5,115 & $\mathrm{CO}$ & Child & MT & Child & $\mathrm{C}$ & TV & $\mathrm{CS}$ & Beh \\
\hline Nathanson \& Cantor, 2000 & 351 & $\mathrm{AM}, \mathrm{RM}, \mathrm{CO}$ & Parent & AG & Child & $\mathrm{C}$ & TV & EX & Beh \\
\hline Nathanson, 1998 & 210-396 & $\mathrm{AM}, \mathrm{RM}, \mathrm{CO}$ & Parent & AG & Child & $\mathrm{C}$ & TV & EX & Beh \\
\hline Nathanson, 1999 & 112-394 & $\mathrm{AM}, \mathrm{RM}, \mathrm{CO}$ & Parent & AG & Child & $\mathrm{C}$ & TV & EX & Both \\
\hline Nathanson, 2001b & 167 & $\mathrm{AM}, \mathrm{CO}$ & Child & AG & Child & $\mathrm{C}$ & TV & $\mathrm{CS}$ & Beh \\
\hline Nathanson, 2004 & 123 & $\mathrm{AM}$ & Child & AG & Child & $\mathrm{C}$ & TV & EX & Att \\
\hline Nikken \& de Graaf, 2013 & 528 & $\mathrm{AM}, \mathrm{RM}$ & Child & SX & Child & A & MM & LG & Both \\
\hline Nikken \& Jansz, 2004 & 536 & $\mathrm{AM}, \mathrm{RM}, \mathrm{CO}$ & Both & MT, MC & Parent & $\mathrm{C}$ & VG & $\mathrm{CS}$ & Beh \\
\hline Nikken \& Schols, 2015 & 896 & $\mathrm{AM}, \mathrm{RM}, \mathrm{CO}$ & Parent & MT & Parent & $\mathrm{C}$ & MM & CS & Beh \\
\hline Padilla-Walker, Coyne, \& Collier, 2016 & 681 & $\mathrm{RM}, \mathrm{AM}$ & Parent & AG & Child & A & MM & LG, CS & Beh \\
\hline Padilla-Walker et al., 2012 & 276 & $\mathrm{AM}, \mathrm{RM}, \mathrm{CO}$ & Children & MT & Both & A & MM & LG & Beh \\
\hline Parkes et al., 2013 & 2,335 & $\mathrm{RM}, \mathrm{CO}$ & Child & SX, SU, MT & Child & A & MM & $\mathrm{CS}$ & Beh \\
\hline Patriarca et al., 2009 & 1,034 & $\mathrm{RM}$ & Child & MT & Child & A & MM & $\mathrm{CS}$ & Beh \\
\hline Pieters et al., 2014 & 1,926 & $\mathrm{RM}$ & Child & MT & Child & A & MM & $\mathrm{CS}$ & Beh \\
\hline Ramirez et al., 2011 & 160 & $\mathrm{RM}$ & Child & MT & Child & A & MM & $\mathrm{CS}$ & Beh \\
\hline Rasmussen, 2014 & 144 & $\mathrm{AM}$ & Parent & AG & Both & $\mathrm{C}$ & TV & EX & Att \\
\hline \multicolumn{10}{|l|}{ Rutherford, Brown, Skouteris, Fuller- } \\
\hline Tyszkiewicz, \& Bittman, 2015 & 4,464 & $\mathrm{RM}$ & Parent & MT & Parent & $\mathrm{C}$ & MM & $\mathrm{CS}$ & Beh \\
\hline \multicolumn{10}{|l|}{ Salmon, Timperio, Telford, Carver, \& } \\
\hline Crawford, 2005 & 2,096 & $\mathrm{RM}$ & Parent & MT & Parent & $\mathrm{C}$ & TV & $\mathrm{CS}$ & Beh \\
\hline \multicolumn{10}{|l|}{ Sargent, Dalton, Heatherton, \& Beach, } \\
\hline 2003 & 4,893 & $\mathrm{RM}, \mathrm{CO}$ & Child & SU & Child & $\mathrm{C}$ & TV & $\mathrm{CS}$ & Beh \\
\hline Sargent et al., 2004 & 2,596 & $\mathrm{RM}, \mathrm{CO}$ & Child & SU & Child & $\mathrm{C}$ & TV & $\mathrm{CS}$ & Beh \\
\hline Schooler et al., 2006 & $267-332$ & $\mathrm{AM}, \mathrm{RM}$ & Child & MT, SX & Child & A & TV & $\mathrm{CS}$ & Beh \\
\hline Shin \& Huh, 2011 & 1,102 & $\mathrm{RM}, \mathrm{CO}$ & Parent & MT & Child & $\mathrm{C}$ & VG & $\mathrm{CS}$ & Beh \\
\hline Singh \& Kaur, 2000 & 200 & RM & Child & MT & Child & $\mathrm{C}$ & $\mathrm{TV}$ & $\mathrm{CS}$ & Beh \\
\hline Skoien \& Berthelsen, 1996 & $160-166$ & $\mathrm{CO}$ & Parent & MT & Parent & $\mathrm{C}$ & VG & CS & Beh \\
\hline Springer et al., 2010 & 734 & RM & Child & MT & Child & $\mathrm{C}$ & $\mathrm{TV}$ & $\mathrm{CS}$ & Beh \\
\hline Sun, 2009 & $337-719$ & $\mathrm{AM}, \mathrm{RM}, \mathrm{CO}$ & Child & MT & Child & $\mathrm{C}$ & TV & CS & Beh \\
\hline te Velde et al., 2011 & 1,248 & $\mathrm{RM}$ & Child & MT & Child & A & TV & CS & Beh \\
\hline Thompson \& Gunther, 2007 & 1,687 & $\mathrm{RM}$ & Child & SU & Child & $\mathrm{C}$ & $\mathrm{TV}$ & $\mathrm{CS}$ & Both \\
\hline Truglio et al., 1996 & 326 & RM & Parent & MT, MC & Parent & $\mathrm{C}$ & TV & $\mathrm{CS}$ & Beh \\
\hline \multicolumn{10}{|l|}{ Valkenberg, Piotrowski, Hermanns, \& de } \\
\hline Leeuw, 2013 & 499 & $\mathrm{AM}, \mathrm{RM}$ & Child & AG & Child & $\mathrm{C}$ & MM & $\mathrm{CS}$ & Beh \\
\hline Van den Bulck \& Van den Bergh, 2000 & 258 & $\mathrm{AM}, \mathrm{RM}$ & Child & MT & Child & $\mathrm{C}$ & MM & $\mathrm{CS}$ & Beh \\
\hline
\end{tabular}




\begin{tabular}{|c|c|c|c|c|c|c|c|c|c|}
\hline Study & $N$ & $\begin{array}{l}\text { Type of } \\
\text { parental } \\
\text { mediation }\end{array}$ & $\begin{array}{l}\text { Parental } \\
\text { mediation } \\
\text { report }\end{array}$ & Outcome & $\begin{array}{l}\text { Outcome } \\
\text { report }\end{array}$ & Age & $\begin{array}{l}\text { Media } \\
\text { type }\end{array}$ & $\begin{array}{l}\text { Study } \\
\text { type }\end{array}$ & $\begin{array}{l}\text { Att vs. } \\
\text { Beh }\end{array}$ \\
\hline $\begin{array}{l}\text { Vandewater, Park, Huang, \& Wartella, } \\
2005\end{array}$ & 838 & $\mathrm{RM}, \mathrm{CO}$ & Parent & $\mathrm{AG}, \mathrm{MT}$ & Parent & $\mathrm{C}$ & TV & CS & Beh \\
\hline Warren, Gerke, \& Kelly, 2002 & 321 & $\mathrm{AM}, \mathrm{RM}, \mathrm{CO}$ & Parent & MT & Parent & $\mathrm{C}$ & TV & CS & Beh \\
\hline White, Rasmussen, \& King, 2015 & 482 & RM & Child & MT & Child & A & MM & CS & Att \\
\hline Woolf, 2010 & $1,221-1,565$ & AM, RM, CO & Parent & $\mathrm{MT}, \mathrm{MC}$ & Child & $\mathrm{C}$ & TV & CS & Beh \\
\hline Zhao \& Phillips, 2013 & 171 & $\mathrm{AM}, \mathrm{RM}, \mathrm{CO}$ & Parent & MT & Parent & $\mathrm{C}$ & TV & $\mathrm{CS}$ & Beh \\
\hline
\end{tabular}

Note. $\quad \mathrm{AM}=$ active mediation; $\mathrm{RM}=$ restrictive mediation $\mathrm{CO}=$ co-viewing $\mathrm{AG}=$ aggression $\mathrm{MC}=$ media content $\mathrm{MT}=$ media time; $\mathrm{SU}=$ substance use; $\mathrm{SX}=$ sexual outcomes; $\mathrm{C}=$ childhood $(0-12$ years old $) ; \mathrm{A}=$ adolescence $(13-17$ years old); $\mathrm{IN}=$ internet; $\mathrm{MM}=$ multiple mediums; $\mathrm{M} / \mathrm{V}=$ movies/videos; $\mathrm{TV}=$ television; $\mathrm{VG}=$ video game; $\mathrm{CS}=$ cross sectional; $\mathrm{EX}=$ experimental; $\mathrm{LG}=$ longitudinal; Att $=$ Attitude; $\mathrm{Beh}=$ behavior.

of oral sex or vaginal intercourse) were collected to further understand sexual outcomes in relation to parental mediation.

\section{Coding of Studies}

The following variables were analyzed from each study: (a) outcomes (i.e., media time, aggression, substance use, and sexual behavior), (b) type of mediation (i.e., restrictive, active, or coviewing/coplaying), (c) study design (i.e., experimental, cross-sectional and longitudinal), (d) media viewed/type (i.e., TV, video game, Internet, movies/videos, or multiple media), (e) parental mediation reporter and outcome reporter (i.e., parent, child, both), (f) outcome being a change in attitude or behavior in childhood or adolescence (i.e., attitudes toward sexual behavior or sexual behavior itself), (g) average age of child (i.e., childhood (0-12 years), adolescence (13-17 years), and (h) type of publication (i.e., published or unpublished data). Eight independent coders were trained on variable definitions and identification by jointly coding examples and openly discussing coding protocols as they were applied. To maintain consistency, coders were split into four groups of two. Coding pairs then came to $100 \%$ consensus on all coding by returning to studies and discussing any coding differences.

\section{Computation of Effect Sizes}

To analyze the results, Comprehensive Meta-analysis II (CMA) software was used. All effect sizes were converted to the Pearson correlation coefficient $(r)$. In the case where the correlation coefficients were not reported $(k=30)$, we contacted corresponding authors via e-mail to obtain $r$. If no response from authors was given $(k=20)$, we used available standardized regression coefficients $(\beta)$ through a deterministic imputation formula $(r=\beta+$ $.05 \lambda$ where $\lambda$ is 1 if $\beta$ is non-negative and 0 if $\beta$ is negative) to transform $\beta$ s into predicted $r$ s for use in our meta-analysis (Peterson \& Brown, 2005). Although this imputation has limitations, it is superior to replacing the missing correlations with zero or with the mean of all the correlations or excluding the study (Peterson \& Brown, 2005).

For the studies that reported multiple effect sizes (e.g., separate correlations for substance use attitudes and substance use behaviors), we used a shifting unit of analysis approach thus recording each statistical test as if it were an independent sample (Cooper, 1989). In order to provide an overall effect size estimate, the four effect-size estimates were averaged. By doing so, the shifting unit of analysis retains as much data as possible without violating the independence assumption that underlies the validity of metaanalytic procedures.

\section{Statistical Analyses}

The analyses were conducted separately for each of the different types of mediation (active, restrictive, and coviewing/coplaying), as well as each of the moderators specified above. Analyses were only performed when there were four or more independent effect size estimates available to discourage interpreting underpowered analyses. Groups of effect sizes that contained less than five studies were still analyzed, but should be interpreted with caution. Analyses were conducted using a random effects model to assess the heterogeneity in various subsets of studies. This model enables the results of this study to be generalizable outside of the articles included in this meta-analysis (Borenstein, Hedges, Higgins, \& Rothstein, 2010; Hunter \& Schmidt, 1990).

Each correlation coefficient underwent a Fisher $z$ transformation to normalize its distribution (Silver \& Dunlap, 1987). The average effect size for each outcome was obtained and transformed back into Pearson's $r$ for interpretation. The pooled estimate of $r$ is denoted as $r_{+}$. Significant differences between the zero-order correlations and the transformed $\beta$ s were checked and found to be statistically similar, except for those in the active mediation metaanalysis, which results should therefore be interpreted with some caution. Possible outlier effects were checked using the CMA software, which examined the overall effect size when each study effect was removed one at a time. There were no substantial changes in the overall effect size.

Finally, to explore heterogeneity between the outcomes, a $Q$-test and $I^{2}$ test were performed (Borenstein et al., 2010; Higgins, Thompson, Deeks, \& Altman, 2003). Also, an analysis was conducted to explore the possibility of publication bias (also called selection bias) or the idea that only studies with significant results are published and those with nonsignificant results are less likely to be published, thus biasing the results of the meta-analysis. To examine the potential of selection bias, we used the trim and fill procedure (Duval \& Tweedie, 2000). This method looks for asymmetry in the funnel plot of observed effects and their standard errors, imputing effects of potential missing studies when asymmetry is found to create a symmetry of effects in the funnel plot. An adjusted effect size is then calculated taking into account the 
imputed studies. When studies are imputed on the left of the funnel plot to create symmetry, it indicates that a mean effect size may be overestimated.

\section{Results}

\section{Restrictive Mediation}

The overall effect size between restrictive mediation and the various child outcomes was significant, $r_{+}=-.06, p<.001,95 \%$ CI $[-.02,-.10], k=48$. The analyses revealed significant relationships between restrictive mediation and sexual outcomes, $r_{+}=-.10, p<.01,95 \% \mathrm{CI}[-.04,-.17], k=6$; and media use, $r_{+}=-.06, p<.01,95 \%$ CI $[-.02,-.11], k=35$; but nonsignificant findings for aggression, and substance abuse, though they were in the expected direction. Analyses revealed that no substantial outliers were confounding these effects. See Table 2 for all restrictive mediation point estimates and $Q$ values. In order to account for publication bias or potential missing studies that would bias the restrictive mediation effect size, Duval and Tweedie's trim and fill procedure was utilized suggested eight missing studies to the right of the mean which would produce a slightly stronger effect size, $r_{+}=-.09,95 \%$ CI $[-.06,-.13]$.

Moderator analyses. A heterogeneity analysis revealed significant variation for the restrictive mediation data, $Q=550.13$, $p<.001, I^{2}=91.50$, justifying follow-up moderator analyses. As such, the effect sizes of the following moderators were analyzed, being theoretically supported to account for the heterogeneity: medium used, age of child, parental mediation reporter, outcome reporter, as well as whether the type of parental mediation influenced an attitude or behavior. Study design and type of publication were not analyzed as moderators due to insufficient variation among possible studies. Despite the significant heterogeneity of the data, none of the existing moderators significantly explained the heterogeneity among the restrictive mediation meta-analysis.

\section{Active Mediation}

The overall effect size between active mediation and the various child outcomes was not significant, $r_{+}=-.02, p=.267,95 \% \mathrm{CI}$ $[.02,-.07], k=30$. The analyses revealed significant relationships between active mediation and aggression, $r_{+}=-.08, p<.001$, 95\% CI [-.03, -.13], $k=7$; sexual outcomes, $r_{+}=-.06, p<$ $.01,95 \%$ CI $[-.02,-.10], k=5$; substance use (though this was underpowered due to a lack of studies and should be interpreted with caution), $r_{+}=-.11, p<.01,95 \%$ CI $[-.04,-.18], k=4$; and media use had nonsignificant findings. No outliers were substantially distorting these effects. All active mediation point estimates and $Q$ values can be seen in Table 3. The trim and fill procedure suggested no bias to the left or right.

Moderator analyses. A heterogeneity analysis revealed significant variation for the active mediation data, $Q=157.44, p<$ $.001, I^{2}=84.55$, justifying follow-up moderator analyses. However, none of the existing moderators significantly explained the heterogeneity among the active mediation meta-analysis.

\section{Coviewing}

The overall effect size between coviewing and the various child outcomes was significant, $r_{+}=.09, p<.001,95 \%$ CI $[.06, .13]$, $k=31$. The analyses revealed significant relationships between coviewing and aggression, $r_{+}=.09, p<.01,95 \%$ CI $[.03, .16]$, $k=12$; and media use, $r_{+}=.12, p<.001,95 \%$ CI $[.08, .15], k=$ 16; but substance use and sexual outcomes contained an insuffi-

Table 2

Characteristics of Restrictive Mediation on Study Variables

\begin{tabular}{lcccccc}
\hline Explanatory variable & $\begin{array}{c}\text { Number of } \\
\text { studies (k) }\end{array}$ & $\begin{array}{c}\text { Point } \\
\text { estimate }\end{array}$ & $p$-value & $Q$-Value & $\begin{array}{c}p \text {-value for } \\
Q \text { statistic }\end{array}$ & $I$-squared \\
\hline Restrictive Mediation & 48 & -.06 & .001 & 550.13 & .000 & 91.50 \\
Outcomes & & & & & & \\
Media time & 35 & -.06 & .007 & & & \\
Aggression & 06 & -.03 & .439 & & & \\
Substance use & 03 & -.06 & .545 & & & \\
Sexual outcomes & 06 & -.10 & .003 & & & \\
Moderators & & & & & & \\
Medium used & 49 & -.05 & .001 & 1.16 & & \\
TV/Movies/Videos & 24 & -.08 & .093 & & & \\
Video games/Internet & 08 & -.01 & .827 & & & \\
Multiple media used & 19 & -.08 & .177 & & & \\
Age of child & 49 & -.06 & .001 & .92 & .339 & \\
Childhood (3-12 years) & 31 & -.05 & .056 & & & \\
Adolescence (13-17 years) & 18 & -.08 & .003 & & & \\
Parental mediation report & 49 & -.05 & .002 & 1.20 & .754 & \\
Child & 28 & -.07 & .004 & & & \\
Parent & 20 & -.05 & .113 & & & \\
Both & 02 & -.03 & .846 & & & \\
Outcome report & 49 & -.06 & .001 & .71 & .701 & \\
Child & 34 & -.07 & .001 & & & \\
Parent & 14 & -.04 & .335 & & & \\
Attitudes vs. behaviors & 49 & -.06 & .001 & .48 & .788 & \\
Attitudes & 07 & -.05 & .078 & & & \\
Behaviors & 47 & -.06 & .002 & & & \\
& & & & &
\end{tabular}


Table 3

Characteristics of Active Mediation on Study Variables

\begin{tabular}{|c|c|c|c|c|c|c|}
\hline Explanatory variable & $\begin{array}{l}\text { Number of } \\
\text { studies (k) }\end{array}$ & $\begin{array}{c}\text { Point } \\
\text { estimate }\end{array}$ & $p$-value & $Q$-Value & $\begin{array}{l}p \text {-value for } \\
Q \text { statistic }\end{array}$ & $I$-squared \\
\hline Active mediation & 30 & -.02 & .267 & 157.44 & .000 & 84.55 \\
\hline \multicolumn{7}{|l|}{ Outcomes } \\
\hline Media time & 17 & .02 & .545 & & & \\
\hline Aggression & 07 & -.08 & .001 & & & \\
\hline Substance use & 04 & -.11 & .002 & & & \\
\hline Sexual outcomes & 05 & -.06 & .003 & & & \\
\hline \multicolumn{7}{|l|}{ Moderators } \\
\hline Medium used & 30 & -.03 & .201 & 4.38 & .112 & \\
\hline TV/Movies/Videos & 19 & -.05 & .038 & & & \\
\hline Video games/Internet & 02 & .12 & .189 & & & \\
\hline Multiple media used & 09 & -.00 & .940 & & & \\
\hline Age of child & 30 & -.04 & .015 & 1.08 & .298 & \\
\hline Childhood (3-9 years) & 19 & -.01 & .751 & & & \\
\hline Adolescence $(10-17$ years) & 11 & -.05 & .009 & & & \\
\hline Parental mediation report & 30 & -.04 & .034 & 3.40 & .493 & \\
\hline Child & 15 & -.04 & .042 & & & \\
\hline Parent & 13 & -.04 & .353 & & & \\
\hline Both & 02 & -.03 & .846 & & & \\
\hline Experimenter & 01 & -.01 & .927 & & & \\
\hline Outcome report & 30 & -.04 & .015 & 1.33 & .515 & \\
\hline Child & 22 & -.04 & .028 & & & \\
\hline Parent & 06 & .03 & .691 & & & \\
\hline Both & 02 & -.07 & .132 & & & \\
\hline Attitudes vs. behaviors & 30 & -.05 & .002 & 3.18 & .204 & \\
\hline Attitudes & 10 & -.11 & .000 & & & \\
\hline Behaviors & 26 & .01 & .654 & & & \\
\hline
\end{tabular}

cient amount of studies for analysis. No outliers were substantially distorting these effects. See Table 4 for all coviewing mediation point estimates and $Q$ values. The trim and fill test did revealed a potential of 3 missing studies to the left of the mean which would increase the effect size $r_{+}=.10,95 \%$ CI $[.07, .13]$.

Moderator analyses. A heterogeneity analysis revealed significant variation for the coviewing data, $Q=130.38, p<.001$, $I^{2}=71.19$, justifying follow-up moderator analyses. Parental report of child outcomes had a significantly greater effect size $\left(r_{+}=.14, p<.001, k=9\right)$ than child report $\left(r_{+}=.04, p=.14\right.$, $k=11) ;(Q=11.85, p<.01)$. Similarly, effects sizes were significantly greater when both parent and child reports of child outcomes were collected $\left(r_{+}=.13, p<.001, k=11\right)$ in comparison to only child self-reports $\left(r_{+}=.04, p=.14, k=11\right) ;(Q=$ $3.96, p<.05)$. None of the other moderators explain the significant heterogeneity of the data.

\section{Discussion}

The purpose of this meta-analysis was to synthesize the research on the effectiveness of different types of parental mediation and commonly researched outcomes in childhood and adolescence. Essentially, three separate meta-analyses were performed, one for each type of parental mediation: restrictive mediation, active mediation, and coviewing. Once separated, we analyzed associations between type of parental mediation and child/adolescent outcomes, specifically: media time, aggression, substance use, and sexual outcomes. Moreover, we examined a number of potential moderators to the results. Meaningful analyses on type of publication and study design were not reported due to insufficient variation or reports on the variable.

\section{Restrictive Mediation}

The intent of restrictive mediation is to protect children from negative media influences. Overall, the results revealed that restrictive mediation of child and adolescent media plays a small, but statistically significant role in preventing negative outcomes, but appears to be strongest for two specific outcomes: media time and sexual outcomes.

The findings of this meta-analysis suggest that parental restrictive mediation may help to decrease the amount of time children spend with media, as children are far exceeding the suggested amount of media the AAP has deemed ideal for development (Rideout et al., 2010). Restrictive mediation also decreases child and adolescent exposure to mature content (Bushman \& Anderson, 2009; EscobarChaves et al., 2005). Media time and content may be directly influencing the child outcomes, thus potentially mediating the interaction between restrictive mediation and child outcomes, such as academic performance (Cummings \& Vandewater, 2007; Wiecha, Sobol, Peterson, \& Gortmaker, 2001) and physical well-being (Cain \& Gradisar, 2010; Christakis et al., 2004). Future research should explore these potential mediational effects in greater depth. These results support the general goal of parental monitoring, in that parental supervision and control protects children and adolescents from harmful exposure of media and negative outcomes.

Restrictive mediation was also a predictor of later and fewer sexual outcomes for children and adolescents. Reports have shown the consistent predictive nature of sexual media for child and adolescent sexual behavior (Brown \& Bobkowski, 2011). Consequently, by implementing specific time and content rules about media, parents limit child exposure to media and assist in preventing unwanted early sex, pregnancy, and multiple partners for their 
Table 4

Characteristics of Coviewing Mediation on Study Variables

\begin{tabular}{|c|c|c|c|c|c|c|}
\hline Explanatory variable & $\begin{array}{l}\text { Number of } \\
\text { studies (k) }\end{array}$ & $\begin{array}{l}\text { Point } \\
\text { estimate }\end{array}$ & $p$-value & $Q$-Value & $\begin{array}{l}p \text {-value for } \\
Q \text { statistic }\end{array}$ & $I$-squared \\
\hline Coviewing mediation & 31 & .09 & .000 & 130.38 & .000 & 71.19 \\
\hline \multicolumn{7}{|l|}{ Outcomes } \\
\hline Media time & 16 & .12 & .000 & & & \\
\hline Aggression & 12 & .09 & .004 & & & \\
\hline Substance use & 02 & .01 & .922 & & & \\
\hline Sexual outcomes & 03 & .03 & .506 & & & \\
\hline \multicolumn{7}{|l|}{ Moderators } \\
\hline Medium used & 31 & .11 & .000 & 3.49 & .175 & \\
\hline TV/Movies/Videos & 15 & .07 & .011 & & & \\
\hline Video games/Internet & 13 & .12 & .000 & & & \\
\hline Multiple media used & 03 & .12 & .000 & & & \\
\hline Age of child & 30 & .09 & .000 & 2.21 & .137 & \\
\hline Childhood (3-9 years) & 27 & .10 & .000 & & & \\
\hline Adolescence $(10-17$ years) & 04 & .02 & .655 & & & \\
\hline Parental mediation report & 31 & .10 & .768 & 3.54 & .178 & \\
\hline Child & 18 & .06 & .010 & & & \\
\hline Parent & 11 & .12 & .000 & & & \\
\hline Both & 02 & .20 & .002 & & & \\
\hline Outcome report & 31 & .11 & .000 & 7.23 & .027 & \\
\hline Child & 11 & .04 & .144 & & & \\
\hline Parent & 09 & .14 & .000 & & & \\
\hline Both & 11 & .13 & .000 & & & \\
\hline Attitudes vs. behaviors & 31 & .07 & .000 & 11.44 & .003 & \\
\hline Attitudes & 02 & -.01 & .768 & & & \\
\hline Behaviors & 30 & .10 & .000 & & & \\
\hline
\end{tabular}

child or adolescent (DiClemente et al., 2001; Fisher et al., 2009; Schooler et al., 2006).

The meta-analysis revealed that restrictive mediation had no direct impact on aggression or substance use in children and adolescents. This may be due to insufficient studies on the topics or the contradictory nature of the results. Instead of restricting exposure to media with or without substance use and/or aggression, parents may have greater likelihood of preventing child and adolescent substance use and/or aggression by using active mediation, as will be discussed later.

Contrary to previous findings (Nathanson, 2002) and selfdetermination theory (Grolnick et al., 1997), restrictive mediation was not found to influence children and adolescents differently. Current measurements of restrictive mediation may not be sensitive enough to distinguish between hard restrictive rules of media early in childhood and the looser rules parents may set in adolescence that allow teens the autonomy that they are seeking while maintaining sufficient media boundaries. Nor are current measures likely to catch a shift in the rule strictness, whether it be gradual or abrupt. Parental limitations of media, in moderate amounts, have proven effective during adolescence, thus allowing some flexibility between the teen and parent on media rules (Guo \& Nathanson, 2011). Parents may use active mediation in addition to their previously held restrictive media rules, which when combined, may be most effective (Gentile, Reimer, Nathanson, Walsh, \& Eisenmann, 2014). Further research should focus on the comparison of single and combined influences of active and restrictive mediation.

\section{Active Mediation}

The purpose of active mediation is to openly discuss media content with children and adolescents to help them develop critical thinking skills about the content being consumed. The current study found that active mediation may provide a protective effect on children's vulnerability to negative effects of media on aggression, substance use, and sexual outcomes; whereas active mediation had no significant influence on media time. None of the moderators explained the variation of the results. Consistent with self-determination theory (Grolnick et al., 1997; Kerr et al., 2010), discussions with parents about media content may provide children and adolescents with the autonomy to develop critical thinking skills to decipher the realistic portrayals of aggression, substance use, and sexual behavior in the media.

Our results revealed that active mediation was associated with lower levels of aggression in children and adolescents. By using active mediation, parents are able to discuss appropriate and realistic attitudes and behaviors, thus helping children and adolescents develop a more critical view of aggressive behavior. Aggression is rampant in TV programs, films, video games, and music (Anderson et al., 2003). This may be one reason why restrictive mediation was not particularly effective in reducing aggressive behavior. Even with a reduction in media time, children still get a strong message from the media that aggression is often justified and normative. Instead, parents can use active mediation to try to combat these messages from the media. They can teach children that aggression is rarely justified, not normative, and results in very real and long-lasting consequences, a message that the mass media typically does not send.

Active discussions about media were also shown to be preventative measures toward decreased desire for and use of substances. The media, at times, presents attractive actors using substances in an enticing way without consequences (Dalton et al., 2006), and unless parents use such instances to discuss the unrealistic and 
sometimes dangerous repercussions from substance use, children and adolescents walk away with impractical expectations (Austin et al., 2000).

Similar to restrictive mediation, active mediation was a predictor of later and fewer sexual outcomes in children and adolescents. These have important implications for parents who feel uncomfortable talking to their children about sex; media may provide parents with an opportunity to discuss sex and convey their values and attitudes without forcing their values on their children (since forceful control may backfire on the parents: Valkenburg et al., 2013). Casual, nonthreatening conversations about sex may have a greater influence on children and adolescents than the sex in the media, especially when children are taught to critically analyze the media through these conversations (Guo \& Nathanson, 2011).

It should be noted that there are at least three different types of active mediation (positive, negative, and neutral), but few studies distinguish between them. Despite different types of active mediation likely having varying results, we were unable to separate these forms of active mediation in the current analysis due to low number of studies distinguishing between the forms. This lack of disentanglement may account for the overall nonsignificant findings of active mediation. Future research should differentiate between the varying types of active mediation to explore in greater detail what the influences are on children and adolescents.

\section{Coviewing}

Coviewing is considered any parental consumption of media with a child or adolescent. Our findings indicate that coviewing is associated with increased aggression and media use; however, it is difficult to conclude how coviewing influences substance use or sexual outcomes due to the lack of studies on the subject. Results reveal that coviewing has more significant influence on child outcomes when parents are reporting the outcome variables.

We found that child and adolescent media use increases when parents are regularly coviewing. In accordance with social learning theory (Bandura, 1977), children and adolescents mimic the media consumption habits of models, including their parents. When consuming media with parents, children and adolescents see the rewards of such behavior (i.e., family time; relaxing in front of the $\mathrm{TV}$, computer, etc.) and then consume additional media outside the direct supervision of parents. Increased media use positively correlates with a host of negative child and adolescent outcomes, including aggressive behavior (Nathanson, 1999), TV-induced fear (Paavonen, Roine, Pennonen, \& Lahikainen, 2009), poor academic performance (Cummings \& Vandewater, 2007) and attention problems (Christakis et al., 2004); thus suggesting that parents need to be aware of the example they are setting of media consumption.

Coviewing was also significantly related to higher levels of aggression for both children and adolescents. Most media send a powerful message regarding the acceptability and consequence free nature of aggressive behavior (Coyne \& Archer, 2004; Huesmann, Moise-Titus, Podolski, \& Eron, 2003), which gives children more reason to assimilate these aggressive behaviors as their own. By their mere presence, parents send an implicit message of approval toward aggressive behavior, regardless of one word being spoken (Nathanson, 1999).

Outcome reporter moderated the relationship between coviewing and child outcomes. Due the implicit nature of coviewing, children may be less aware of their behavior related to coviewing when compared to parents who can see it from a third person perspective. Social desirability may also play a role for children when reporting on outcome measures for these studies (Ciaravino, 1991).

The overall coviewing findings suggest that parents should be wary in what they view and how much they view with their children and adolescents, as parents may implicitly be giving their consent for numerous behaviors in the media. Social learning theory alludes that children will mimic media habits as well as behaviors and attitudes they view on TV (Bandura, 1977). One limitation of the current research is that far too few studies have investigated coviewing's influence on substance use and sexual outcomes, in addition to differentiating between intentional and passive coviewing. Future research should focus on parental intentions for purposeful coviewing in which parents hope to give approval of said media and teach values (Chakroff \& Nathanson, 2008); whereas other research should continue to explore the influence passive coviewing has on children and adolescents, especially in regards to substance use and sexual outcomes.

\section{Gaps in the Literature and Directions for Future Research}

The parental mediation literature is growing, but in comparison to the rate of child media consumption as well as the availability of media, the progress is lacking in a number of key areas. Parental mediation should be examined in a broader parenting context (i.e., parental monitoring) and yet the topic consistently remains in the communications field. Parental monitoring of academics, daily activities, and peers maintains the focus of parenting scholars, and many of the same issues in these areas are being dealt with in the parental mediation such as guiding children's media content selection, time management, how to prepare for negative experiences (i.e., mature content), and how to interpret the messages given to children through the media (Mounts, 2011). The parental monitoring conceptualization is even being reevaluated, with current measures discovering that parents are learning more about their child's daily activities from the child's disclosure, than previous parental monitoring measures (i.e., parental control and solicitation). This may also may be the case in terms of media as children obtain their own devices and are exposed to media in all aspects of their lives (Kerr et al., 2010). This area of research needs to combine both the communications and parenting literature to adequately question, analyze and more fully comprehend how parental mediation may help mitigate the negative influence media has on children and adolescents.

Additionally, greater effort needs to be used to disentangle the nuanced aspects of parental mediation. Most authors did not distinguish between different subtypes of mediation, thus requiring us to combine them into general categories in our analyses. As a result, the samples of studies measuring child and adolescent outcomes were limited and impeded moderator analyses for each of the outcomes. For example, most authors did not differentiate between parents who were critical of sexualized media and those who praised sexualized media, labeling both as active mediation. Instead, most studies ask general questions about parental mediation, such as "how often do you talk to your child about media characters," which is more neutral. By increasing the amount of 
studies on the varying types of parental mediation, parents and researchers will know how to better mediate children's consumption of media for optimal child and adolescent development.

This meta-analysis found all types of parental mediation to influence children and adolescents similarly, which contradicts previous research (Nathanson, 2002); however, the cross-sectional nature of previous research is a significant limitation. Only three longitudinal studies on this topic have been reported (Nikken \& de Graaf, 2013; Padilla-Walker, Coyne, \& Collier, 2016), none of which focused on the transition from childhood to adolescence. Future research should focus on longitudinal methods to discover how parental mediation impacts children and adolescents in the long term, as well as whether parental mediation changes between childhood and adolescence.

\section{Conclusion}

Our meta-analysis found that parental mediation of media is a small, but significant predictor of several child and adolescent outcomes including media time, aggression, substance use, and sexual outcomes. The media has become an integral part of daily life among families and may at times feel all-consuming; however, parents have the ability to mitigate some of the adverse effects of the media, through parental mediation. Our understanding of parental mediation will maintain a slow progression until parenting and communications scholars collaborate, recognizing this as a serious developmental issue. The various measures of parental mediation need to be explored and specified (i.e., positive active mediation or intentional coviewing) to obtain standard results for each type of parental mediation. In addition, longitudinal methodology, especially across childhood and adolescence, should be utilized to discern the adapting strategies parents use for different developmental periods. In conclusion, parents need to educate themselves on the harmful and beneficial effects of media and use that knowledge for appropriate parenting such as creating rules for media use, discussing character's choices and central themes, and consuming media together.

\section{References}

References marked with an asterisk indicate studies included in the meta-analysis.

*Abel-Cooper, T. B. (2001). The association between video game playing, religiosity, parental guidance and aggression, in sixth through eighth grade students attending Seventh-Day Adventist Schools. Dissertation Abstracts International, 61(10-A), 3910.

American Academy of Pediatrics Committee on Public Education. (2001). Children, adolescents, and television. Pediatrics, 107, 423-426. http:// dx.doi.org/10.1542/peds.107.2.423

Anderson, C. A., Berkowitz, L., Donnerstein, E., Huesmann, L. R., Johnson, J. D., Linz, D., . . W Wartella, E. (2003). The influence of media violence on youth. Psychological Science in the Public Interest, 4, $81-110$.

Ashby, S. L., Arcari, C. M., \& Edmonson, M. B. (2006). Television viewing and risk of sexual initiation by young adolescents. Archives of Pediatrics \& Adolescent Medicine, 160, 375-380. http://dx.doi.org/10 .1001/archpedi.160.4.375

Austin, E. W. (1993). Exploring the effects of active parental mediation of television content. Journal of Broadcasting \& Electronic Media, 37, 147-158. http://dx.doi.org/10.1080/08838159309364212
Austin, E. W., Bolls, P., Fujioka, Y., \& Engelbertson, J. (1999). How and why parents take on the tube. Journal of Broadcasting \& Electronic Media, 43, 175-192. http://dx.doi.org/10.1080/08838159909364483

*Austin, E. W., \& Chen, Y. J. (2003). The relationship of parental reinforcement of media messages to college students' alcohol-related behaviors. Journal of Health Communication, 8, 157-169. http://dx.doi .org/10.1080/10810730305688

*Austin, E. W., Pinkleton, B. E., \& Fujioka, Y. (2000). The role of interpretation processes and parental discussion in the media's effects on adolescents' use of alcohol. Pediatrics, 105, 343-349. http://dx.doi.org/ 10.1542/peds.105.2.343

Bandura, A. (1977). Social learning theory. Oxford, UK: Prentice Hall.

*Barkin, S., Ip, E., Richardson, I., Klinepeter, S., Finch, S., \& Krcmar, M. (2006). Parental media mediation styles for children aged 2 to 11 years. Archives of Pediatrics \& Adolescent Medicine, 160, 395-401. http://dx .doi.org/10.1001/archpedi.160.4.395

*Barradas, D. T., Fulton, J. E., Blanck, H. M., \& Huhman, M. (2007). Parental influences on youth television viewing. The Journal of Pediatrics, 151, 369-373.e4. http://dx.doi.org/10.1016/j.jpeds.2007.04.069

*Bauer, K. W., Neumark-Sztainer, D., Fulkerson, J. A., Hannan, P. J., \& Story, M. (2011). Familial correlates of adolescent girls' physical activity, television use, dietary intake, weight, and body composition. The International Journal of Behavioral Nutrition and Physical Activity, 8, 25. http://dx.doi.org/10.1186/1479-5868-8-25

Bersamin, M., Todd, M., Fisher, D. A., Hill, D. L., Grube, J. W., \& Walker, S. (2008). Parenting practices and adolescent sexual behavior: A longitudinal study. Journal of Marriage and the Family, 70, 97-112. http:// dx.doi.org/10.1111/j.1741-3737.2007.00464.x

Borenstein, M., Hedges, L. V., Higgins, J. P., \& Rothstein, H. R. (2010). A basic introduction to fixed-effect and random-effects models for meta-analysis. Research Synthesis Methods, 1, 97-111. http://dx.doi.org/ $10.1002 / \mathrm{jrsm} .12$

*Borzekowski, D. G., \& Robinson, T. N. (2007). Conversations, control, and couch-time. Journal of Children \& Media, 1, 162-176. http://dx.doi .org/10.1080/17482790701339183

Brown, J. D., \& Bobkowski, P. S. (2011). Older and newer media: Patterns of use and effects on adolescents' health and well-being. Journal of Research on Adolescence, 21, 95-113. http://dx.doi.org/10.1111/j.15327795.2010.00717.x

Brown, J. D., L’Engle, K. L., Pardun, C. J., Guo, G., Kenneavy, K., \& Jackson, C. (2006). Sexy media matter: Exposure to sexual content in music, movies, television, and magazines predicts black and white adolescents' sexual behavior. Pediatrics, 117, 1018-1027. http://dx.doi .org/10.1542/peds.2005-1406

Brummert Lennings, H. I., \& Warburton, W. A. (2011). The effect of auditory versus visual violent media exposure on aggressive behaviour: The role of song lyrics, video clips and musical tone. Journal of Experimental Social Psychology, 47, 794-799. http://dx.doi.org/10 .1016/j.jesp.2011.02.006

Bushman, B. J., \& Anderson, C. A. (2009). Comfortably numb: Desensitizing effects of violent media on helping others. Psychological Science, 20, 273-277. http://dx.doi.org/10.1111/j.1467-9280.2009.02287.x

Cain, N., \& Gradisar, M. (2010). Electronic media use and sleep in school-aged children and adolescents: A review. Sleep Medicine, 11, 735-742. http://dx.doi.org/10.1016/j.sleep.2010.02.006

${ }^{*}$ Carlson, S. A., Fulton, J. E., Lee, S. M., Foley, J. T., Heitzler, C., \& Huhman, M. (2010). Influence of limit-setting and participation in physical activity on youth screen time. Pediatrics, 126, e89-e96. http:// dx.doi.org/10.1542/peds.2009-3374

Chakroff, J. L., \& Nathanson, A. I. (2008). Parent and school interventions: Mediation and media literacy. In S. L. Calvert \& B. J. Wilson (Eds.), The handbook of children, media, and development (pp. 552-576). Malden, MA: Blackwell Publishing. http://dx.doi.org/10.1002/9781444302752 . $\operatorname{ch} 24$ 
${ }^{*}$ Choo, H., Sim, T., Liau, A. K., Gentile, D. A., \& Khoo, A. (2015). Parental influences on pathological symptoms of video-gaming among children and adolescents: A prospective study. Journal of Child and Family Studies, 24, 1429-1441. http://dx.doi.org/10.1007/s10826-0149949-9

Christakis, D. A., Zimmerman, F. J., DiGiuseppe, D. L., \& McCarty, C. A. (2004). Early television exposure and subsequent attentional problems in children. Pediatrics, 113, 708-713. http://dx.doi.org/10.1542/peds.113 .4 .708

Ciaravino, J. G. (1991). Two factor theory of social desirability responding and bias reduction in children's self-reports. Hempstead, NY: Hofstra University.

*Cillero, I. H., \& Jago, R. (2011). Sociodemographic and home environment predictors of screen viewing among Spanish school children. Journal of Public Health, 33, 392-402. http://dx.doi.org/10.1093/ pubmed/fdq087

Cooper, H. M. (1989). Integrating research: A guide for literature reviews (2nd ed.). Thousand Oaks, CA: Sage.

Coyne, S. M., \& Archer, J. (2004). Indirect aggression in the media: A content analysis of British television programs. Aggressive Behavior, 30, 254-271. http://dx.doi.org/10.1002/ab.20022

*Coyne, S. M., Padilla-Walker, L. M., Stockdale, L., \& Day, R. D. (2011). Game on ... girls: Associations between co-playing video games and adolescent behavioral and family outcomes. Journal of Adolescent Health, 49, 160-165. http://dx.doi.org/10.1016/j.jadohealth.2010.11 .249

Coyne, S. M., Robinson, S. L., \& Nelson, D. A. (2010). Does reality backbite? Physical, verbal, and relational aggression in reality television programs. Journal of Broadcasting \& Electronic Media, 54, 282-298. http://dx.doi.org/10.1080/08838151003737931

Cummings, H. M., \& Vandewater, E. A. (2007). Relation of adolescent video game play to time spent in other activities. Archives of Pediatrics \& Adolescent Medicine, 161, 684-689. http://dx.doi.org/10.1001/ archpedi.161.7.684

"Dalton, M. A., Adachi-Mejia, A. M., Longacre, M. R., Titus-Ernstoff, L. T., Gibson, J. J., Martin, S. K., . . Beach, M. L. (2006). Parental rules and monitoring of children's movie viewing associated with children's risk for smoking and drinking. Pediatrics, 118, 1932-1942. http://dx.doi .org/10.1542/peds.2005-3082

Dalton, M. A., Sargent, J. D., Beach, M. L., Titus-Ernstoff, L., Gibson, J. J., Ahrens, M. B., . . . Heatherton, T. F. (2003). Effect of viewing smoking in movies on adolescent smoking initiation: A cohort study. The Lancet, 362, 281-285. http://dx.doi.org/10.1016/S01406736(03)13970-0

*Darweesh, A. S., \& Mahmoud, A. H. (2014). Parental mediation of adolescents' internet use in Jordan. Journal of Arab \& Muslim Media Research, 7, 205-218. http://dx.doi.org/10.1386/jammr.7.2-3.205_1

de Leeuw, R. N., Blom, H., \& Engels, R. C. (2014). Parental co-viewing and susceptibility for smoking and drinking in adolescents: An experimental pilot study. The American Journal on Addictions, 23, 349-356. http://dx.doi.org/10.1111/j.1521-0391.2014.12108.x

*Desmond, R., \& Duran, R. (2011, May). The benefits of early parental TV mediation on young adults' critical media skills. Paper presented at International Communication Association, Boston, MA.

DiClemente, R. J., Wingood, G. M., Crosby, R., Sionean, C., Cobb, B. K., Harrington, K., . . O Oh, M. K. (2001). Parental monitoring: Association with adolescents' risk behaviors. Pediatrics, 107, 1363-1368. http://dx .doi.org/10.1542/peds.107.6.1363

Dorr, A., Kovaric, P., \& Doubleday, C. (1989). Parent-child coviewing of television. Journal of Broadcasting \& Electronic Media, 33, 35-51.

Duval, S., \& Tweedie, R. (2000). A nonparametric "trim and fill" method of accounting for publication bias in meta-analysis. Journal of the American Statistical Association, 95, 89-98.
*Engelhardt, C. R., \& Mazurek, M. O. (2014). Video game access parental rules, and problem behavior: A study of boys with autism spectrum disorder. Autism, 18, 529-537. http://dx.doi.org/10.1177/ 1362361313482053

Escobar-Chaves, S. L., Tortolero, S. R., Markham, C. M., Low, B. J., Eitel, P., \& Thickstun, P. (2005). Impact of the media on adolescent sexual attitudes and behaviors. Pediatrics, 116, 303-326.

"Fisher, D. A., Hill, D. L., Grube, J. W., Bersamin, M. M., Walker, S., \& Gruber, E. L. (2009). Televised sexual content and parental mediation: Influences on adolescent sexuality. Media Psychology, 12, 121-147. http://dx.doi.org/10.1080/15213260902849901

*Fujioka, Y., \& Austin, E. W. (2003). The implications of vantage point in parental mediation of television and child's attitudes toward drinking alcohol. Journal of Broadcasting \& Electronic Media, 47, 418-434. http://dx.doi.org/10.1207/s15506878jobem4703_6

Gentile, D. A., Reimer, R. A., Nathanson, A. I., Walsh, D. A., \& Eisenmann, J. C. (2014). Protective effects of parental monitoring of children's media use: A prospective study. Journal of the American Medical Association Pediatrics, 168, 479-484. http://dx.doi.org/10.1001/ jamapediatrics.2014.146

Grolnick, W. S., Deci, E. L., \& Ryan, R. M. (1997). Internalization within the family: The self-determination theory perspective. In J. E. Grusec \& L. Kuczynski (Eds.), Parenting and children's internalization of values: A handbook of contemporary theory (pp. 135-161). Hoboken, NJ: Wiley.

Grusec, J. E., \& Goodnow, J. J. (1994). Impact of parental discipline methods on the child's internalization of values: A reconceptualization of current points of view. Developmental Psychology, 30, 4-19. http:// dx.doi.org/10.1037/0012-1649.30.1.4

*Guo, W., \& Nathanson, A. I. (2011). The effects of parental mediation of sexual content on the sexual knowledge, attitudes, and behaviors of adolescents in the US. Journal of Children and Media, 5, 358-378. http://dx.doi.org/10.1080/17482798.2011.587141

"Hanewinkel, R., Morgenstern, M., Tanski, S. E., \& Sargent, J. D. (2008). Longitudinal study of parental movie restriction on teen smoking and drinking in Germany. Addiction, 103, 1722-1730. http://dx.doi.org/10 .1111/j.1360-0443.2008.02308.x

*Hardy, L. L., Baur, L. A., Garnett, S. P., Crawford, D., Campbell, K. J., Shrewsbury, V. A., . . . Salmon, J. (2006). Family and home correlates of television viewing in 12-13 year old adolescents: The Nepean Study. The International Journal of Behavioral Nutrition and Physical Activity, 3, 24. http://dx.doi.org/10.1186/1479-5868-3-24

"Harrison, K., \& Liechty, J. M. (2012). US preschoolers' media exposure and dietary habits: The primacy of television and the limits of parental mediation. Journal of Children and Media, 6, 18-36. http://dx.doi.org/ 10.1080/17482798.2011.633402

Higgins, J. P., Thompson, S. G., Deeks, J. J., \& Altman, D. G. (2003). Measuring inconsistency in meta-analyses. British Medical Journal: British Medical Journal, 327, 557-560. http://dx.doi.org/10.1136/bmj .327.7414.557

Hogan, M. J. (2012). Parents and other adults: Models and monitors of healthy media habits. In D. G. Singer \& J. L. Singer (Eds.), Handbook of children and the media (2nd ed., pp. 661-680). Thousand Oaks, CA Sage.

Huesmann, L. R., Moise-Titus, J., Podolski, C. L., \& Eron, L. D. (2003). Longitudinal relations between children's exposure to TV violence and their aggressive and violent behavior in young adulthood: 1977-1992. Developmental Psychology, 39, 201-221. http://dx.doi.org/10.1037/ 0012-1649.39.2.201

Hunter, J. E., \& Schmidt, F. L. (1990). Methods of meta-analysis: Correcting error and bias in research findings. Thousand Oaks, CA: Sage.

"Johnson, L., Chen, T. A., Hughes, S. O., \& O'Connor, T. M. (2015). The association of parent's outcome expectations for child TV viewing with parenting practices and child TV viewing: An examination using path 
analysis. The International Journal of Behavioral Nutrition and Physical Activity, 12, 70. http://dx.doi.org/10.1186/s12966-015-0232-2

Kerr, M., \& Stattin, H. (2000). What parents know, how they know it, and several forms of adolescent adjustment: Further support for a reinterpretation of monitoring. Developmental Psychology, 36, 366-380. http://dx.doi.org/10.1037/0012-1649.36.3.366

Kerr, M., Stattin, H., \& Burk, W. J. (2010). A reinterpretation of parental monitoring in longitudinal perspective. Journal of Research on Adolescence, 20, 39-64. http://dx.doi.org/10.1111/j.1532-7795.2009.00623.x

"Lee, S. (2013). Parental restrictive mediation of children's internet use: Effective for what and for whom? New Media \& Society, 15, 466-481. http://dx.doi.org/10.1177/1461444812452412

*Lin, C. A., \& Atkin, D. J. (1989). Parental mediation and rulemaking for adolescent use of television and VCRs. Journal of Broadcasting \& Electronic Media, 33, 53-67. http://dx.doi.org/10.1080/ 08838158909364061

"Linder, J. R., \& Werner, N. E. (2012). Relationally aggressive media exposure and children's normative beliefs: Does parental mediation matter? Family Relations, 61, 488-500. http://dx.doi.org/10.1111/j 1741-3729.2012.00707.x

"Livingstone, S., \& Helsper, E. J. (2008). Parental mediation of children's internet use. Journal of Broadcasting \& Electronic Media, 52, 581-599. http://dx.doi.org/10.1080/08838150802437396

"McDade-Montez, E., Wallander, J., Elliott, M., Grunbaum, J. A., Tortolero, S., Cuccaro, P., \& Schuster, M. A. (2015). TV viewing, perceived similarity, coviewing, and mental well-being among African American, Latino, and White children. The Journal of Early Adolescence, 35, 329-352. http://dx.doi.org/10.1177/0272431614531655

Mounts, N. S. (2011). Parental management of peer relationships and early adolescents' social skills. Journal of Youth and Adolescence, 40, 416427. http://dx.doi.org/10.1007/s10964-010-9547-0

"Nathanson, A. I. (1998). The immediate and cumulative effects of television mediation on children's aggression. Dissertation Abstracts International: Section A, 59, 2236.

*Nathanson, A. I. (1999). Identifying and explaining the relationship between parental mediation and children's aggression. Communication Research, 26, 124-143. http://dx.doi.org/10.1177/009365099026002002

Nathanson, A. I. (2001a). Mediation of children's television viewing: Working toward conceptual clarity and common understanding. In W. B. Gudykunst (Ed.), Communication yearbook 25 (pp. 115-151). Mahwah, NJ: Erlbaum. http://dx.doi.org/10.1207/s15567419cy2501_4

*Nathanson, A. I. (2001b). Parents versus peers exploring the significance of peer mediation of antisocial television. Communication Research, 28, 251-274. http://dx.doi.org/10.1177/009365001028003001

Nathanson, A. I. (2002). The unintended effects of parental mediation of television on adolescents. Media Psychology, 4, 207-230. http://dx.doi .org/10.1207/S1532785XMEP0403_01

*Nathanson, A. I. (2004). Factual and evaluative approaches to modifying children's responses to violent television. Journal of Communication, 54, 321-336. http://dx.doi.org/10.1111/j.1460-2466.2004.tb02631.x

*Nathanson, A. I., \& Cantor, J. (2000). Reducing the aggressionpromoting effect of violent cartoons by increasing children's fictional involvement with the victim: A study of active mediation. Journal of Broadcasting \& Electronic Media, 44, 125-142. http://dx.doi.org/10 .1207/s15506878jobem4401_9

*Nikken, P., \& de Graaf, H. (2013). Reciprocal relationships between friends' and parental mediation of adolescents' media use and their sexual attitudes and behavior. Journal of Youth and Adolescence, 42, 1696-1707. http://dx.doi.org/10.1007/s10964-012-9873-5

Nikken, P., \& Jansz, J. (2004, May). Parental mediation of children's video game playing: A similar construct as television mediation. Paper presented at the International Communication Association: Communication Research in the Public Interest, New Orleans, Louisiana.
*Nikken, P., \& Schols, M. (2015). How and why parents guide the media use of young children. Journal of Child and Family Studies, 24, 34233435. http://dx.doi.org/10.1007/s10826-015-0144-4

Paavonen, E. J., Roine, M., Pennonen, M., \& Lahikainen, A. R. (2009). Do parental co-viewing and discussions mitigate TV-induced fears in young children? Child: Care, Health and Development, 35, 773-780. http://dx .doi.org/10.1111/j.1365-2214.2009.01009.x

*Padilla-Walker, L. M., Coyne, S. M., \& Collier, K. M. (2016). Longitudinal relations between parental media monitoring and adolescent aggression, prosocial behavior, and externalizing problems. Journal of Adolescence, 46, 86-97. http://dx.doi.org/10.1016/j.adolescence.2015 .11 .002

*Padilla-Walker, L. M., Coyne, S. M., Fraser, A. M., Dyer, W. J., \& Yorgason, J. B. (2012). Parents and adolescents growing up in the digital age: Latent growth curve analysis of proactive media monitoring. Journal of Adolescence, 35, 1153-1165. http://dx.doi.org/10 .1016/j.adolescence.2012.03.005

*Parkes, A., Wight, D., Hunt, K., Henderson, M., \& Sargent, J. (2013). Are sexual media exposure, parental restrictions on media use and coviewing TV and DVDs with parents and friends associated with teenagers' early sexual behaviour? Journal of Adolescence, 36, 1121-1133. http://dx.doi.org/10.1016/j.adolescence.2013.08.019

*Patriarca, A., Di Giuseppe, G., Albano, L., Marinelli, P., \& Angelillo, I. F. (2009). Use of television, videogames, and computer among children and adolescents in Italy. BMC Public Health, 9, 139. http://dx.doi.org/ 10.1186/1471-2458-9-139

Peterson, R. A., \& Brown, S. P. (2005). On the use of beta coefficients in meta-analysis. Journal of Applied Psychology, 90, 175-181. http://dx .doi.org/10.1037/0021-9010.90.1.175

*Pieters, D., De Valck, E., Vandekerckhove, M., Pirrera, S., Wuyts, J., Exadaktylos, V., . . . Cluydts, R. (2014). Effects of pre-sleep media use on sleep/wake patterns and daytime functioning among adolescents: The moderating role of parental control. Behavioral Sleep Medicine, 12, 427-443. http://dx.doi.org/10.1080/15402002.2012.694381

*Ramirez, E. R., Norman, G. J., Rosenberg, D. E., Kerr, J., Saelens, B. E., Durant, N., \& Sallis, J. F. (2011). Adolescent screen time and rules to limit screen time in the home. Journal of Adolescent Health, 48, 379 385. http://dx.doi.org/10.1016/j.jadohealth.2010.07.013

*Rasmussen, E. (2014). Explaining parent-child discussions of television: Active mediation as a proxy for attitude accessibility. Unpublished manuscript, Texas Tech University, Lubbock, TX.

Rideout, V. J., Foehr, U. G., \& Roberts, D. F. (2010). Generation $M^{2}$ : Media in the Lives of 8- to 18-Year-Olds. Menlo Park, CA: Henry J. Kaiser Family Foundation.

*Rutherford, L., Brown, J. E., Skouteris, H., Fuller-Tyszkiewicz, M., \& Bittman, M. (2015). Screen media, parenting practices, and the family environment in Australia: A longitudinal study of young children's media use, lifestyles, and outcomes for healthy weight. Journal of Children and Media, 9, 22-39. http://dx.doi.org/10.1080/17482798 .2015.997101

"Salmon, J., Timperio, A., Telford, A., Carver, A., \& Crawford, D. (2005). Association of family environment with children's television viewing and with low level of physical activity. Obesity Research, 13, 19391951. http://dx.doi.org/10.1038/oby.2005.239

*Sargent, J. D., Beach, M. L., Dalton, M. A., Ernstoff, L. T., Gibson, J. J., Tickle, J. J., \& Heatherton, T. F. (2004). Effect of parental R-rated movie restriction on adolescent smoking initiation: A prospective study. Pediatrics, 114, 149-156. http://dx.doi.org/10.1542/peds.114.1.149

*Sargent, J. D., Dalton, M. A., Heatherton, T., \& Beach, M. (2003). Modifying exposure to smoking depicted in movies: A novel approach to preventing adolescent smoking. Archives of Pediatrics \& Adolescent Medicine, 157, 643-648. http://dx.doi.org/10.1001/archpedi.157.7.643

Schooler, C., Feighery, E., \& Flora, J. A. (1996). Seventh graders' selfreported exposure to cigarette marketing and its relationship to their 
smoking behavior. American Journal of Public Health, 86, 1216-1221. http://dx.doi.org/10.2105/AJPH.86.9.1216

*Schooler, D., Kim, J. L., \& Sorsoli, L. (2006). Setting rules or sitting down: Parental mediation of television consumption and adolescent self-esteem, body image, and sexuality. Sexuality Research \& Social Policy, 3, 49-62. http://dx.doi.org/10.1525/srsp.2006.3.4.49

*Shin, W., \& Huh, J. (2011). Parental mediation of teenagers' video game playing: Antecedents and consequences. New Media \& Society, 13, 945-962. http://dx.doi.org/10.1177/1461444810388025

Silver, N. C., \& Dunlap, W. P. (1987). Averaging correlation coefficients: Should Fisher's $z$ transformation be used? Journal of Applied Psychology, 72, 146-148. http://dx.doi.org/10.1037/0021-9010.72.1.146

Singer, J. L., Singer, D. G., Desmond, R., Hirsch, B., \& Nicol, A. (1988). Family mediation and children's cognition, aggression, and comprehension of television: A longitudinal study. Journal of Applied Developmental Psychology, 9, 329-347. http://dx.doi.org/10.1016/01933973(88)90034-2

*Singh, P., \& Kaur, D. (2000). A study of parent-child-interaction and parental restrictions on TV viewing among children. Psycho-Lingua, 30, 31-36.

*Skoien, P., \& Berthelsen, D. (1996). Video games: Parental beliefs and practices. In 5th Australian Family Research Conference (Vol. 10, p. 2009). Brisbane, Australia: Australian Institute of Family Studies.

*Springer, A. E., Kelder, S. H., Barroso, C. S., Drenner, K. L., Shegog, R., Ranjit, N., \& Hoelscher, D. M. (2010). Parental influences on television watching among children living on the Texas-Mexico border. Preventive Medicine, 51, 112-117. http://dx.doi.org/10.1016/j.ypmed.2010.05.013

Steinberg, L. D. (2013). Adolescence (10th ed.). New York, NY: McGrawHill.

St. Peters, M., Fitch, M., Huston, A. C., Wright, J. C., \& Eakins, D. J. (1991). Television and families: What do young children watch with their parents? Child Development, 62, 1409-1423. http://dx.doi.org/10 .1111/j.1467-8624.1991.tb01614.x

*Sun, T. (2009). Parental mediation of children's TV viewing in China: An urban-rural comparison. Young Consumers, 10, 188-198. http://dx.doi .org/10.1108/17473610910986008

"te Velde, S. J., van der Horst, K., Oenema, A., Timperio, A., Crawford, D., \& Brug, J. (2011). Parental and home influences on adolescents' TV viewing: A mediation analysis. International Journal of Pediatric Obesity, 6, e364-e372. http://dx.doi.org/10.3109/17477166.2010.490264

*Thompson, E. M., \& Gunther, A. C. (2007). Cigarettes and cinema: Does parental restriction of R-rated movie viewing reduce adolescent smoking susceptibility? Journal of Adolescent Health, 40, 181.e1-181.e6. http:// dx.doi.org/10.1016/j.jadohealth.2006.09.017
*Truglio, R. T., Murphy, K. C., Oppenheimer, S., Huston, A. C., \& Wright, J. C. (1996). Predictors of children's entertainment television viewing: Why are they tuning in? Journal of Applied Developmental Psychology, 17, 475-493. http://dx.doi.org/10.1016/S0193-3973(96)90012-X

Valkenburg, P. M., Krcmar, M., Peeters, A. L., \& Marseille, N. M. (1999). Developing a scale to assess three styles of television mediation: "Instructive mediation," "restrictive mediation," and "social coviewing". Journal of Broadcasting \& Electronic Media, 43, 52-66. http://dx.doi .org/10.1080/08838159909364474

*Valkenburg, P. M., Piotrowski, J. T., Hermanns, J., \& de Leeuw, R. (2013). Developing and validating the perceived parental media mediation scale: A self-determination perspective. Human Communication Research, 39, 445-469. http://dx.doi.org/10.1111/hcre.12010

"Van den Bulck, J., \& Van den Bergh, B. (2000). The influence of perceived parental guidance patterns on children's media use: Gender differences and media displacement. Journal of Broadcasting \& Electronic Media, 44, 329-348. http://dx.doi.org/10.1207/ s15506878jobem4403_1

*Vandewater, E. A., Park, S., Huang, X., \& Wartella, E. A. (2005). 'No-you can't watch that': Parental rules and young children's media use. American Behavioral Scientist, 48, 608-623. http://dx.doi.org/10 $.1177 / 0002764204271497$

*Warren, R., Gerke, P., \& Kelly, M. A. (2002). Is there enough time on the clock?: Parental involvement and mediation of children's television viewing. Journal of Broadcasting \& Electronic Media, 46, 87-111. http://dx.doi.org/10.1207/s15506878jobem4601_6

"White, S. R., Rasmussen, E. E., \& King, A. J. (2015). Restrictive mediation and unintended effects: Serial multiple mediation analysis explaining the role of reactance in U.S. adolescents. Journal of Children and Media, 9, 510-527. http://dx.doi.org/10.1080/17482798.2015.1088873

Wiecha, J. L., Sobol, A. M., Peterson, K. E., \& Gortmaker, S. L. (2001). Household television access: Associations with screen time, reading, and homework among youth. Ambulatory Pediatrics, 1, 244-251. http://dx .doi.org/10.1367/1539-4409(2001)001<0244:HTAAWS > 2.0.CO;2

"Woolf, K. D. (2009). Children, parents and prosocial television for children: Accounting for viewing and looking for effects (Doctoral dissertation). Available from ProQuest, Paper AAI3395728. Retrieved from http://repository.upenn.edu/dissertations/AAI3395728

*Zhao, Y., \& Phillips, B. M. (2013). Parental influence on children during educational television viewing in immigrant families. Infant and Child Development, 22, 401-421. http://dx.doi.org/10.1002/icd.1798

Received June 24, 2015

Revision received January 14, 2016 Accepted January 21, 2016 